\title{
THE EFFECT OF TOTAL PHSYICAL RESPONSE (TPR) METHOD ON STUDENTS' SPEAKING ACHIEVEMENT; A CASE OF NINETH GRADE STUDENTS OF SMPN 1 KABAWO
}

\author{
Waode Siti Wardani \\ Dra. Nurnia, M.A. \\ Siam, S.Pd., M.TESOL. \\ English Department \\ Halu Oleo University
}

Email: waodesitiwardani@gmail.com

\begin{abstract}
This study was aimed at finding out whether there is a significant effect of Total Physical Response (TPR) method on students' speaking achievement. The research question addressed was "is there any significant effect of Total Physical Response (TPR) method on students' speaking achievement?" The design of study was quasi experimental design by using two classes, namely experimental class and control class. This study involved the ninth grade students of SMPN 1 Kabawo who were registered in the academic year $2017 / 2018$. The instrument of the study was oral test where the students performed in front of the class orally about how to make a glass of ice lemon in 3 minutes. The study used independent sample t- test to analyze the data. The result showed that the students' speaking score in experimental class (3.12) was higher than students' speaking score in control class (2.23). The result of hypothesis testing revealed that the level of significant was 0.00. It means that there was a significant difference on students' speaking achievement after being taught by using total physical response.
\end{abstract}

Keywords: Speaking, Teaching Speaking, Total Physical Response

\section{Introduction}

In learning speaking, the students sometimes find some problems to make a communication well. The problem probably occurs because they are worried about making mistake, getting critic or losing face in front of the class. It is because the students 
come from different background that have many kinds of language in their village. Their first language might make them feel difficult to say something in English. So that, the students are shy to make a communication because they could not pronounce English well. This statement is supported by Kartini (2010) who said that anxiety about constructing errors when speaking in front of class is the problem faced by the students. According to Tsiplakides (2009), students who display communication nervousness do not feel comfortable communicating in the target language in front of others, due to their limited knowledge of the language, especially in relation to speaking skill. Not only that, the students sometimes have lack of motivation to learn English because they think that English is not important for them and it is difficult for them to use English in their daily conversation. Those problems could appear because of the teaching method, strategy, technique and media in learning English especially speaking which is not interesting for the students.

One of methods which could be used in teaching speaking is Total Physical Response (TPR). The learning model of Total Physical Response (TPR) is students respond to the teacher's instruction physically. In TPR method, students will be more active in teaching learning process. This method can improve speaking, listening, vocabulary achievement. Asher (1965) said that students could speak easily by action because it is easier for the students to remember something by action than by memorizing. Through TPR, the students can speak directly in front of the class without focusing on memorizing context. In TPR, students are not forced to speak but the teacher will wait for the students to speak spontaneously if they have been ready. For the first time, the teacher will give some instructions to make the students familiar 
with the topic that they will learn. After that, teacher hopes the students are ready to speak directly. Thus, it can make the students feel free in speaking activity without pressure from the other people.

The research question of this study is "is there any significant effect of Total Physical Response (TPR) method on students' speaking achievement at SMPN 1 Kabawo?”

\section{Research Method}

The design of the study was quasi experimental design which used two classes, namely: experimental class and control class. English score in Raport Book was used as the pre-test score and students were given post-test after treatment. Experimental class was taught by using Total Physical Response (TPR) method and control class was taught by using conventional/regular teaching method.

There were two variables in the study, namely:

1. Independent variable refers to the Effect of Total Physical Response (TPR) method.

2. Dependent variable was students' speaking achievement.

The population of the study was all the ninth grade students of SMPN 1 Kabawo who were registered in academic year 2017 / 2018. The total numbers of student at the ninth grade were 195 students from 9 classes. They were class IX ${ }^{\mathrm{A}}$, class $\mathrm{IX}^{\mathrm{B}}$, class IXC, classIX' ${ }^{\mathrm{D}}$, class $\mathrm{IX}^{\mathrm{E}}$, class $\mathrm{IX}^{\mathrm{F}}$, class $\mathrm{IX}^{\mathrm{G}}$, class $\mathrm{IX}^{\mathrm{H}}$, and Class $\mathrm{IX}^{\mathrm{I}}$. The sample of this study was class IX ${ }^{\mathrm{A}}$ as the experimental class which consisted of 22 students and class IX ${ }^{B}$ as the control class which consisted of 22 students.

The Instrument of the study was oral test where the students were asked to perform in front of the class with the topic about "How to make a glass of ice lemon" during 3 minutes for each 
students. The students' performance was video recorded. The score of speaking achievement used band score proposed by Ur (1996) for fluency and accuracy.

The Scale of oral testing criteria for fluency

\begin{tabular}{|l|l|}
\hline Fluency & 1 \\
\hline Little or no communication & 2 \\
\hline $\begin{array}{l}\text { Very shy and brief statement, sometimes difficult } \\
\text { Gets ideas across, but hesitantly and briefly }\end{array}$ & 3 \\
\hline Effective communication in short turns & 4 \\
\hline Essay and effective communications use long terms & 5 \\
\hline
\end{tabular}

The Band Score of Speaking Accuracy

\begin{tabular}{|l|l|}
\hline Accuracy & 1 \\
\hline Little or no produce & 2 \\
\hline $\begin{array}{l}\text { Poor vocabulary, mistakes in basic grammar, strong } \\
\text { foregin accent }\end{array}$ & 2 \\
\hline $\begin{array}{l}\text { Adequate but not rich vocabulary makes obvious } \\
\text { grammar mistakes, slight foregin accent }\end{array}$ & 3 \\
\hline $\begin{array}{l}\text { Good range of vocabulary, occasional grammar slips, } \\
\text { slight foregin accent }\end{array}$ & 4 \\
\hline $\begin{array}{l}\text { Wide vocabulary appropriately use, virtually no grammar } \\
\text { mistakes, } \\
\text { Native-like or slight foreign accent }\end{array}$ & 5 \\
\hline
\end{tabular}

The procedure of scoring speaking achievement, as follows:

1. Both raters were given band score for fluency and accuracy

2. Both raters watched students' performance in video and scored it.

Prior to conducting this study, a pilot study was conducted at Class IXC of SMPN 1 Kabawo on February 19th 2018. It was conducted to know the effectiveness of time allocation of the instrument that the researcher used and also to check inter rater agreement. From the result of pilot study, the researcher found that the time allocation for doing the instrument in the classroom 
was enough 3 minutes for each students. Thus, the researcher spent 66 minutes for all students in the classroom.

In evaluating the students' speaking score, the researcher used two raters to get more accurate data. The raters were the researcher as the first rater and the English teacher as the second rater.

In dealing with the scale of speaking test used in this study, the researcher tried to make an agreement in order to have same perception with the English teacher. Researcher tried to assess 10 students with the English teacher to see the correlation between the score. The result of pilot study showed that both raters had a high inter rater agreement in giving score to the students based on the students' score classification provided by Ur (1996).

\section{Findings and Discussion}

Descriptive Analysis of Post-test

This section explains the descriptive analysis of students' speaking achievement after being given treatment in experimental class and control class. Students' speaking achievement was measured in two aspects namely: accuracy and fluency.

Descriptive Analysis of Post-test in Experimental Class

The following graph describes the result of students' score on post-test in experimental class.

Graph 1.1 Distribution of Students' Score on Post-test in Experimental Class 


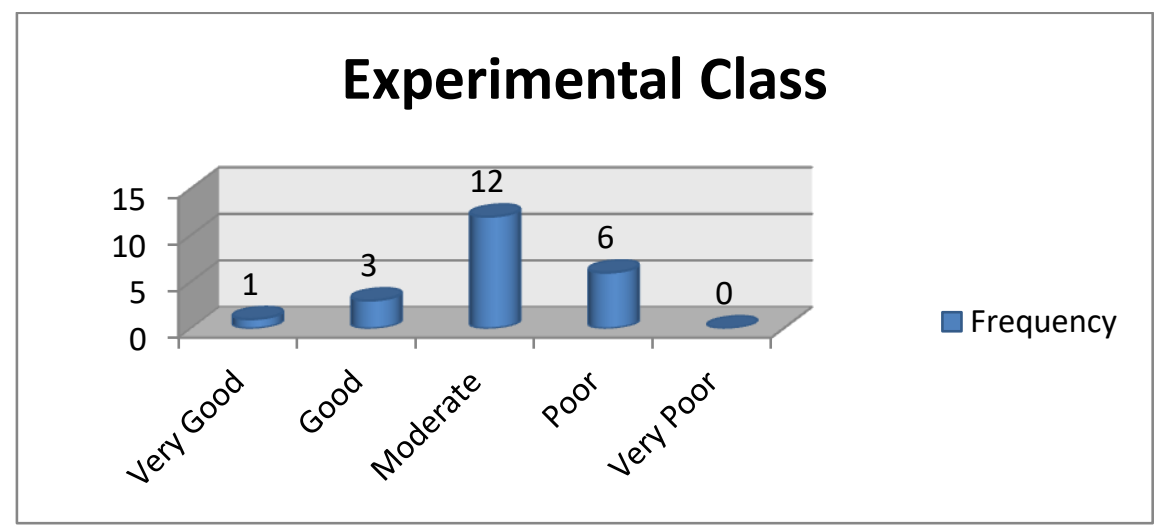

It can be seen from the graph that the highest score in experimental class was classified as moderate criteria. There were 12 students who were on that criterion. It means that there is an effect after used Total Physical Response (TPR) Method in teaching speaking. There was one student classified as very good criteria, 3 students got score classified as good criteria. But, there were still six students who got score classified as poor criteria. In short, we can say that after using Total Physical Response (TPR) method in teaching speaking, the students' speaking score in terms of fluency and accuracy increased.

Descriptive Analysis of Post-test in Control Class

The description below is the result of students' score on post-test in control class. The detail explanation is shown in the following table:

Graph 1.2 Distribution of Students' Post-test Score in Control Class 


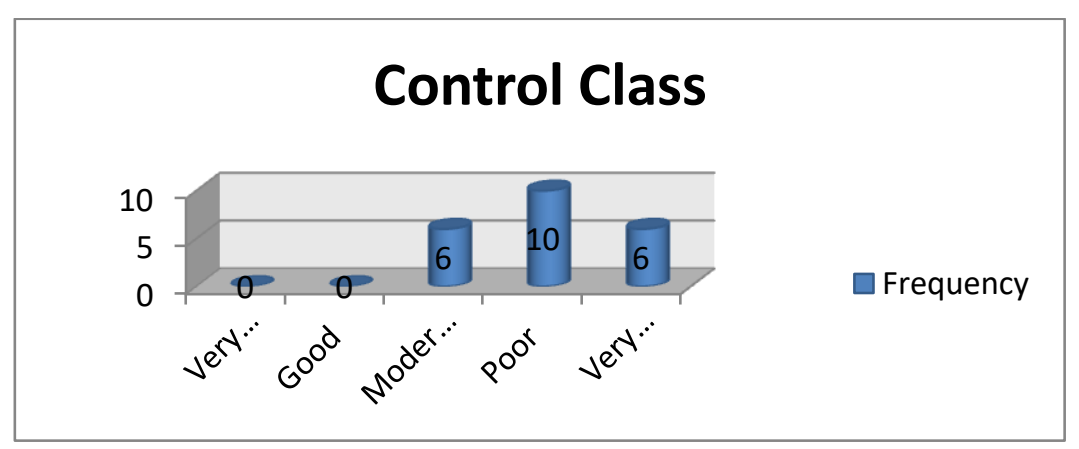

Based on the graph, we can see that the highest students' speaking score in control class was classified as poor criteria. There were 10 students who were classified as poor criteria. Besides, there were still six students got score classified as very poor criteria, and six students got score classified as moderate criteria. In control class, there was not students who got score classified both good and very good criteria.

The Comparison of Post-test Score in Experimental Class and Control Class

The comparison of post-test score in experimental and control class are presented in the following table:

Table 1.3 The Comparison of Post-test Score in Experimental and Control Class

\begin{tabular}{|l|l|l|l|l|l|}
\hline & $\mathrm{N}$ & Minimum & Maximum & Mean & $\begin{array}{l}\text { Std. } \\
\text { Deviation }\end{array}$ \\
\hline Experiment & 22 & 2.00 & 5.00 & 3.1250 & .80456 \\
\hline Control & 22 & 1.00 & 3.50 & 2.2386 & .74991 \\
\hline
\end{tabular}

The table above presents the differences of minimum, maximum, mean score, and standard deviation on post-test in experimental class and post-test in control class. The minimum score on experiment class in post-test was 2 whereas in control class was 1 . Both scores belonged to poor and very poor category but the minimum score in experimental class was higher than the minimum score in control class. The difference was 1 point. 
The comparison between maximum score on post-test both of the class showed different criteria. The value of maximum score in experiment class was 5 and this number belonged to very high criteria whereas the maximum score in control class was 3.50 and the score belonged to very good and moderate criteria. Then, the differences for both of the scores were 1.5 points.

Hypothesis Testing

Before testing the hypothesis, normality test and homogeneity test were calculated. The value for normality test for experimental class was .144 and control class was .066. It means that the data were distributed normally. And the value for homogeneity test was .091. It means that the data were homogeneous. Since the data fulfilled the prerequisite, statistical parametric analysis in the form of independent sample t-test could be calculated.

The hypothesis testing was used to investigate whether or not there was any significant effect of using Total Physical Response (TPR) method on students' speaking achievement at the nineth grade students of SMPN 1 Kabawo by using t-test with significant 0.05 and degree of freedom $(\mathrm{df}=42)$.

The result of hypothesis testing by using Independent sample t-test can be seen in the following table:

Table 1.4 The Result of Hypothesis Testing

\begin{tabular}{|c|c|c|c|c|}
\hline Df & test $_{\text {test }}$ & Symbol & $t_{\text {table }}$ & Result \\
\hline 42 & 3.780 & $>$ & 2.021 & $\mathrm{H}_{0}:$ rejected \\
& & & & $\mathrm{H}_{1}:$ Accepted \\
\hline
\end{tabular}

From the table above, we can see that test was 3.780 and table was 2.021. It means that $t_{\text {test }}$ was higher than $t_{\text {table. }}$ So, the hypothesis was accepted. It means that there was any significant 
effect on students' speaking achievement after being taught by using Total Physical Response (TPR).

The effect size on this analysis is calculated in order to see its' effect. The result of the effect size was 0.6. It indicates that the effect size is categorized into large criteria.

This study revealed that there was effect of teaching speaking by using Total Physical Response (TPR) method on students' speaking achievement. It might be caused by teaching material used, the design of TPR, and learning media. In this case, the students were more interested in learning speaking because they learnt by seeing the real object that the teacher had prepared before. The students did not find any difficulties to speak up because they learn in real situation, not in in imagine situation. Not only that, students more interested in teaching material that the researcher used because the material is usually happen in their daily activity or they familiar with the topic, so that the students don't feel difficult when they want to speak up about the topic is given. Woolfolk (2004) said that students in young age can easy to understand the material that they learn by doing direct experiment in the classroom. The students will more easily understand something quickly through what they does than what they write. And also, they more interested in teaching-learning process because the students' aren't monotonous to speak up in individually but sometimes the students speak up in group, so that it can make the students feel comfortable and more confident to perform in front of the class.

\section{Conclusion}

Based on the finding of the study, it can be seen that there is any significant effect in teaching speaking by using Total Physical Response (TPR) method on students' speaking achievement. It can 
be seen that the mean score of post-test in experimental class is 3.1250 is higher than the mean score of post-test in control class is 2.2386. This score is increased because of applying the Total Physical Response (TPR) method in teaching speaking for the nineth grade students of SMPN 1 Kabawo because the students can easy to speak by action and fluently, so that the students can get the higher score than the control class which used conventional method. Therefore, the result of hypothesis testing is HO rejected and $\mathrm{H} 1$ is accepted.

In short, after considering some findings in this study, the researcher can conclude that teaching speaking by using Total Physical Response (TPR) method can give any significant effect on students' speaking achievement.

It is effective to use Total Physical Response (TPR) method because the student can speak up directly in front of the class. In this study, the researcher find that the students' speaking achievement is increased than before the students are taught by TPR method. So, I suggest to the teacher to apply this method in students' speaking on beginning level.

\section{References}

Ambarsari. Teaching Speaking To Young Learners Using Total Physical Response Method (A Quasy-Experimental Study At The Fifth Grade Of SDN Baros Mandiri V Cimahi). Thesis. English Education Study Program Language and Arts Department Sekolah Tinggi Keguruan dan Ilmu Pendidikan (STKIP) Siliwangi. Bandung

Asher, J. (1965). The strategy of total physical response: an application to learning russian. International Review of Applied Linguistics, 3, 291-300. 
Asher, J. James. The Total Physical Response Approach to Learning Language. www.tprworld.com/organizing.htm. (Accessed on 11 December 2017)

Larsen-Freeman, D. (2000). Techniques and principles in language teaching, Oxford University.

Larsen-Freeman, D. (1990). Language Teaching Methods: Teacher's Handbook for the Video Series, US Department of State.

Penny, U. 1996. A Course in Language Teaching: Practice Theory. Great Britain: Cambridge University Press

Richards, J. C. and T. S. Rodgers Approaches and methods in language teaching, Cambridge university press.

Widodo, H. P. (2005). "Teaching children using a total physical response (TPR) method: Rethinking." Bahasa dan Seni, 33(2): 235-238.

Woolfolk, Anita. (2004). Educational Psychology. (9th ed). Boston: Allyn and Bacon. 